\section{Sergio Mancini}

\section{Stefano Mancini}

General Surgery, University of Siena; Simple Autonomous Operational Unit Phlebolymphology, University Hospital Polyclinic Le Scotte of Siena, Italy

\section{Professor Mancini, a father, a mentor...}

I think no words exist to fully describe Prof. Sergio Mancini to those who never met him and to those who have not shared the daily struggles of work and research with him. An eclectic, autarchic person, never tame, always looking for new input and with the aim of bringing together the entire Italian phlebology before the eyes of the scientific world.

Born in Livorno on $19^{\text {th }}$ October 1937 , he graduated in Medicine in Naples in 1964, then moved to Siena, where he started volunteering and later worked as joint hospital assistant and finally as a university assistant in General Surgery at the Santa Maria della Scala Hospital. In 1980, the hospital moved to the new University Hospital Santa Maria alle Scotte, and he continued his university career there, first as an associate professor in Emergency Surgery and then as Director of General Surgery III in 1990, replacing his teacher, Professor Luciano Lorenzini.

The passion for phlebology led him to found, in 1984, thanks to the funding of the company Pabisch, a dedicated University Specialist Center, where he closed the viewers above the operating general surgery rooms. ${ }^{1}$ The Pabisch Center, later transformed in the Interdepartmental Center for Research, Diagnosis and Phlebo-lymphological Rehabilitation of the University of Siena and currently in Simple Autonomous Operational Unit (Unità Operativa Semplice Autonoma, UOSA) Phlebology, would become an important facility at national and international level.

The center became a school of life and work when a $2^{\text {nd }}$ level university master degree in phlebolymphology was started in the academic years of 2001-02 and 200203.

Mancini's hunger for research and innovation would lead him to experiment with surgical solutions and medical devices in every field of phlebology and lymphology to improve the patients' quality of life.

The first studies were carried out with Dr. Fabrizio Mariani, his assistant at the time, in various fields of phlebology: the lysosomal enzymes involved in chronic venous insufficiency, ${ }^{2}$ the pathophysiology of leg ulcers, ${ }^{3}$ numerous advanced dressings in venous ulcers, including the microfibrillar structure cellulose membrane for superficial lesions and for the coverage of autologous skin grafts, ${ }^{4}$ human fibrin glue for the treatment of leg ulcers and for the engraftment of autologous grafts, the first heterologous grafts with lyophilized pig skin ${ }^{5}$ and the action of sodium carboxymethylcellulose, ${ }^{6}$ which allowed him to go to Copenhagen directly to the company Coloplast to present the results of his research. All the experience on the treatment of ulcers is contained in his first publication on phlebology entitled The treatment of venous ulcers of the lower limbs written together with Dr. Fabrizio Mariani (Figure 1).?

In the field of surgery, he began with the effectiveness of short stripping compared to long stripping of the great saphenous vein in preventing postoperative paresthesia complications, the results of which were presented in 1990 at the $3^{\text {rd }}$ International Congress of SIFL and then at the $12^{\text {th }}$ World Congress of the Union Internationale de Phlébologie (UIP), held in London 3-8 September $1995 .^{\circ}$

Morover, he studied a surgical correction for recurrent vein at the groin starting by $\mathrm{Li}$ technique ${ }^{9,10}$ and the diagnosis and treatment of the anterior saphenous vein. ${ }^{11}$

At the beginning of the $1990 \mathrm{~s}$, the philosophy of the rescue of the incontinent saphenous vein with a haemodynamic modification of the reflux gained support. In France, Dr. Claude Franceschi proposed the CHIVA technique, while in Italy Professor Sergio Mancini started to perform valvuloplasty procedures with a personal technique consisting of an external valve plastic of the preterminal valve of the great saphenous vein, done first with a cribriform fascia, then with Dacron, PTFE and finally with Venocuff. The first experimental studies with the related clinical cases were published in 1991. ${ }^{12}$ Venocuff was then used for the correction of deep venous reflux. ${ }^{13}$

Research on the progression of venous disease leading to valvular insufficiency suggested Mancini to perform a histological study in 2001, which demonstrated the absence of lymphomonocyte infiltration both in the preterminal valve and in the vein wall. ${ }^{14}$

Thanks to Paolo Pierguidi, he started travelling to France and work with Dr. Robert Stemmer at the courses Entretiens angéiologiques d'Oberstaigen to import the sclerosing technique. The first studies on the action of the sclerosing substance on the great saphenous vein wall in vivo on volunteers were presented in 1989 at the World
Correspondence: Stefano Mancini, General Surgery, University of Siena; Simple Autonomous Operational Unit Phlebolymphology, University Hospital Polyclinic Le Scotte of Siena, Italy. E-mail: mancinistefano1967@libero.it

Key words: Italian Phlebolymphology; history; Masters of the past; phlebology; lymphology.

Conflict of interests: the author declares no potential conflict of interests.

This paper is part of the monographic issue: 'Did the Masters of the past know the future? History and update of Italian Phlebolymphology' - Guest editor: Alberto Macciò (Phlebology - Part I edited by G. Agus; Phlebology - Part II edited by P. Bonadeo; Lymphology edited by F. Boccardo).

Received for publication: 30 June 2020

Revision received: 10 July 2020.

Accepted for publication: 15 July 2020 .

This work is licensed under a Creative Commons Attribution 4.0 License (by-nc 4.0).

${ }^{\circ}$ Copyright: the Author(s), 2020

Licensee PAGEPress, Italy

Veins and Lymphatics 2020; 9:9253

doi:10.4081/vl.2020.9253

Congress of Phlebology in Strasbourg ${ }^{15}$ and then the work was published on in $1991 .{ }^{16}$

Sergio Mancini and his school study and developed the sclerotherapy treatment of reticular varices and teleangectasies, but also the treatment of pigmentation postsclerotherapy. ${ }^{17,18}$

Dr. Pierantonio Bacci favored a scientific collaboration between the Center of Phlebology of the University of Siena and the Argentinean Society of Phlebology and Lymphology and the consequent organization of the annual Italian-Argentinean phlebology meetings that took place alternately in Italy and Argentina.

Dr. Eugenio Brizzio, one of the world's leading experts in phlebology and then President of the Argentine Society and vicepresident of UIP, and other Argentinian experts of international renown (such as Dr. Simkin, Dr. Pietravallo and others) became active promoters of the scientific development of phlebology at the Center directed by Prof. Sergio Mancini. In particular Dr. Eugenio Brizzio contributed with studies on plantar pumps in venous return, ${ }^{19}$ on sclerotherapy ${ }^{20}$ and compression (Figure 2).

The result of this cooperation produced a CT study on the compression of peripheral vessels, which was one of the first studies that demonstrated the effects of compression on the superficial and deep vessels of 
the leg during muscle contraction. The results of this study were published in 1992. ${ }^{21}$

A debate also began on the genesis of varicose veins, with the presentation of a study on varicose veins in horses, which, despite passing their lives in orthostatism, do not present a venous disease, to the National Research Center of the Ministry of Education, University and Research, but the study was not accepted.

In 1995, a morphometric comparative study of the therapeutic effects of elastocompression and safenectomy was published on Phlébology. ${ }^{22}$

Dr. Pierantonio Bacci brought to the Phlebologic Center the development of research in the field of aesthetic phlebology, also from a day surgery standpoint, and the introduction in Italy of phlebectomy by mini-incisions, ${ }^{23}$ with multiple publications over the years, from medical treatment in phlebology in $1989^{24}$ to chapters on books on the role of plant-derived drugs on cellulitis, ${ }^{25}$ passing through the first experiences with YAG lasers and electrosurgical scalpels, ${ }^{26}$ but also a book entitled Complicazioni ed emergenze in chirurgia ambulatoriale in 1995. ${ }^{27}$

Professor Sergio Mancini, in collaboration with Dr. Amerigo Brogi (assistant anesthetist at the Policlinic University Hospital Le Scotte), was among the first to introduce in Italy loco-regional anaesthesia techniques of for varicose vein surgery (block 31 and femoral), which allowed for early deambulation and discharge of the patient on the same day of surgery. ${ }^{28,29}$

Through a cousin who was a dentist, Dr. Gianni Moro, Mancini learnt about methylpyrrolidone chitosan, a molecule derived from crab shells, useful for bone and gingival reconstruction, which led him to successfully test its efficacy on the skin lesions of the lower limbs. ${ }^{30}$

In 1995, he founded the Center for Male Sexual Dysfunction at the University of Siena in cooperation with Dr. Roberto Tullii of Sao Paulo de Brazil, which would lead to the development of research on venous drainage in erectile dysfunction. Our results were presented in many international congresses. ${ }^{31-34}$

The cooperation with Professor Baccio Baccetti, head of the Biology Institute of the University of Siena, opened the way to the study of varicocele and male infertility. The sub-inguinal correction technique was developed, and particularly ultrastructural changes of sperm, and chromosome 18, X and $\mathrm{Y}$ aneuploids in III degree varicocele. ${ }^{35}$ The Phlebologic Center is still a milestone for the diagnosis and post-operative control of varicocele in pediatric surgery children. ${ }^{36}$
In 1996, he started a collaboration with the S. Albino spa in Montepulciano, where vascular paths were created for thermal vascular rehabilitation with two tubs at different temperatures $\left(27^{\circ} \mathrm{C}\right.$ and $\left.31^{\circ} \mathrm{C}\right)$ and centripetal and countercurrent wave massage. The results, which proved improvements in microcirculation at laser Doppler, were be published with Professor Coccheri of the University of Bologna. ${ }^{37}$

Dr. Concetta Curti opened up to him the world of integrated or alternative or complementary or biological therapies in phlebolymphology. The study of posture, feet and their phlebolymphological interactions (Dr. Curti), the study of the interstitial matrix (Professor S.B. Curri, Dr. Curti), later continued by Prof. Campisi and Dr. Bacci, the diagnostic-therapeutic approaches of acupuncture, homeopathy, homotoxicology and osteopathy contributed to the clinical study of the patient as a whole and individuality, which returned a sense of wholeness to patients.

The need to deepen the knowledge of physical and clinical processes applied to humans allowed us to study and use thermography, bio-electric currents, polarized light, radiofrequency (Tecar therapy), oxygen-ozone, laser therapy (Dr. Longo). His interest was such that, in addition to specialization courses (1997-2002), which offered a broader and more detailed view of the applications of so-called natural therapies and their biological effects, he also founded the Italian Society of Integrated Therapies in Phlebo-lymphology (SITIF-1996).

The results obtained, presented in many conferences and interuniversity forums, offered the opportunity to other Italian and foreign universities to open up to the knowledge and practice of integration and the synergy of innovative techniques in phlebolymphology. ${ }^{38-40}$

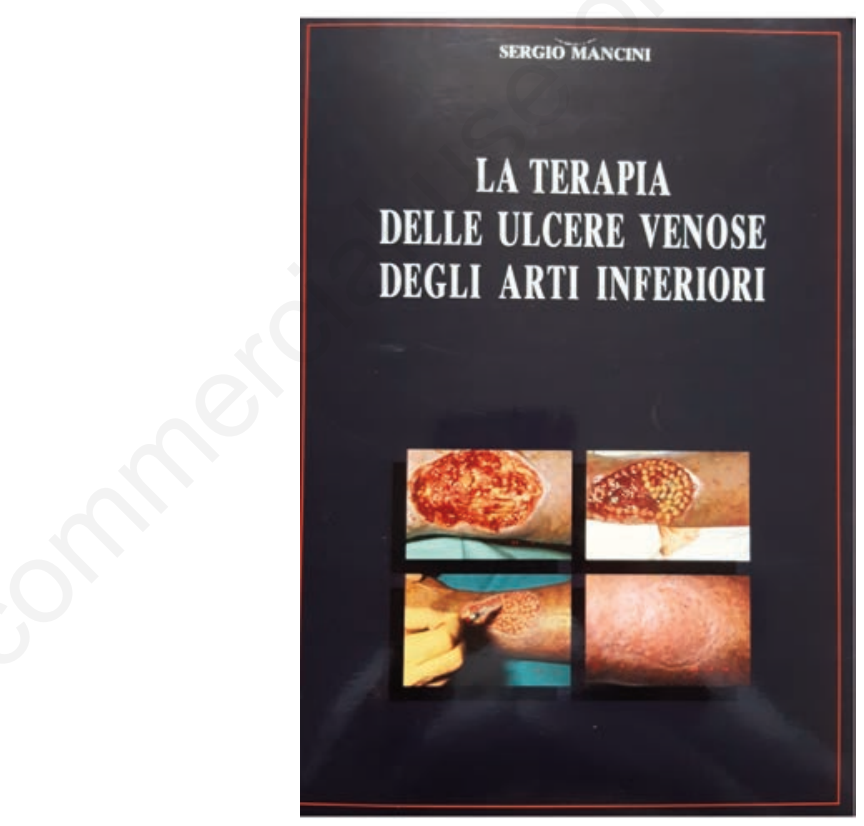

Figure 1. The Treatment of the Venous Ulcers of the Lower Limbs.

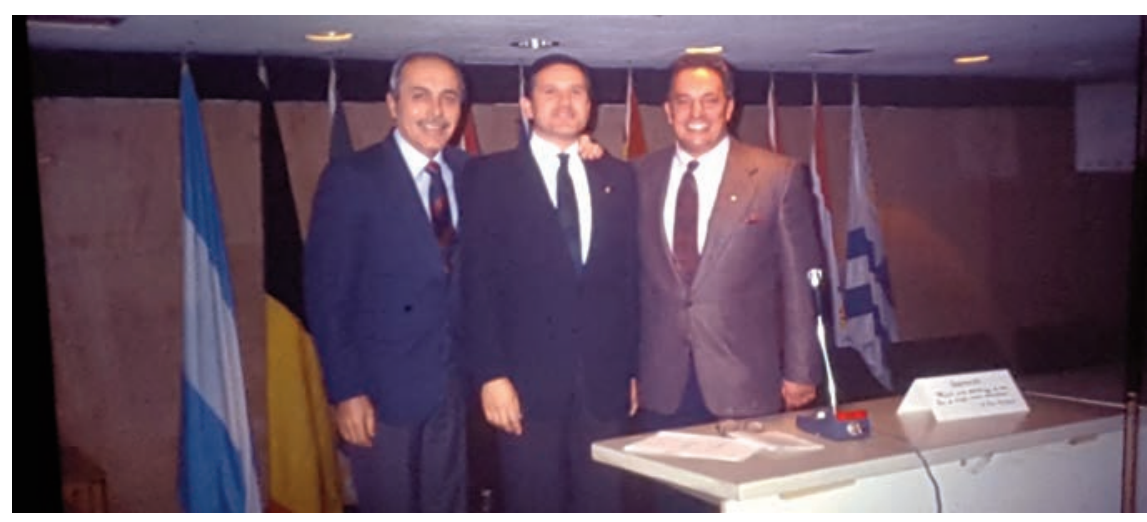

Figure 2. Professor Mancini with Dr. Bacci and Dr. Brizzio.

[Veins and Lymphatics 2020; 98:9253]

[page 51] 
After collaborating with Dr. Leonardo Longo, the use of laser for the treatment of angiomas and telangiectasias, leg ulcers, but also in erectile dysfunction, in the treatment of Peyronie plaques, was introduced at the Center of Phlebology.41-43 For lymphedema, he organized a diagnostic and therapeutic medical and physiotherapeutic protocol with manual lymphatic drainage and pressure therapy. ${ }^{44,45}$ In 1999, the Skin and Tissue Bank of the Dermatology Institute of the University of Siena and Center of Phlebology was founded and immediately he became one of the major users of homologous skin grafts in the treatment of lower limb ulcers. ${ }^{46-49}$ In the same field, a platelet gel was also introduced with excellent results on resistant ulcers, and particularly on amputation stumps, due to the strong stimulation of tissue regrowth. ${ }^{50}$

In 2001, he decided to publish a Treaty on Phlebology and Lymphology consisting of two volumes collecting the entire Italian scientific knowledge in the field of phlebology, together with the experience of some international leading representatives of the discipline (Figure 3). ${ }^{51}$

In the field of surgery, he dealt with the problem of inguinal recurrences by testing the covering of the stump with the cribriform fascia after closing it by invagination, and simultaneously, with Dr. Giuseppe Genovese and Dr. Fabrizio Mariani, he experimented selective crossectomy with the saving of proximal collaterals. It would be with Dr. Fabrizio Mariani that he published the results of his school on selective crossectomy Angiol. ${ }^{52,53}$ With the advent of the scleromousse introduced by Dr. Tessari, Prof. Sergio Mancini used this technique in the treatment of the saphenous vein, particularly the small saphenous vein, and also tested it even after crossectomy to avoid the trauma of stripping. ${ }^{54}$

In 2001, with his assistant Professor Giuseppe Botta, he began using the endovascular laser treatment of the saphenous vein, starting from $810 \mathrm{~nm}$ and up to the current $1470 \mathrm{~nm}$. His experience with the first 100 Italian cases was published in $2006 .{ }^{55}$ The continuous collaboration with Dr. Fabrizio Mariani in the field of sclerotherapy and elastocompression led to the publication of many scientific articles, of which we mention the book on Sclerotherapy (2006), ${ }^{56}$ but above all the Consensus Conference on Compression Therapy (2009). ${ }^{57}$

In the field of elastocompression, studies on skin pressure under elastic stocking ${ }^{58}$ the use of elastic stockings (post-operative kit) in the treatment of saphenous stripping ${ }^{59}$ and ulcer kit for venous ulcers treatment are worth mentioning. ${ }^{60}$
In addition to 622 scientific papers published on national and international journals, numerous chapters on of general surgery manuals and 7 monographs, he was also a member of the Academy of Physiocrats and, above all, in the field of phlebology, in 1986 he took part, with Prof. Ippolito Donnini of the University of Ferrara, in the foundation of the Italian Society of Phlebo-lymphology (SIFL), which he would chair from 1997 to 1999.

In 1996, together with Professor Claudio Allegra and Dr. Giuseppe Genovese, he founded the Italian College of Phlebology, which he chaired in the three-year period 2006-2008. He was one of the authors of the Phlebology Guidelines of the Italian College of Phlebology published in 2000 and of the 2003 and 2013 revisions. ${ }^{61-70}$ In 2009, he decided to publish the knowledge collected by his school in the fields of phlebology and lymphology 25 years after the birth of his Center, as an epilogue of a brilliant career, under the title Manuale di flebologia, esperienza della scuola senese (A Handbook on Phlebology. The experience of the Senese School, Figure 4). ${ }^{71} \mathrm{He}$ retired during that same year and left the Phlebology Center to

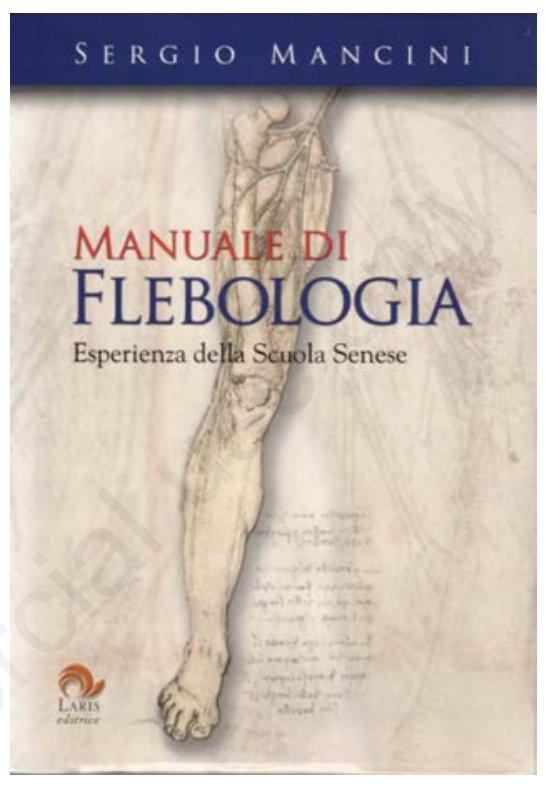

Figure 3. Treaty on Phlebology and Lymphology.

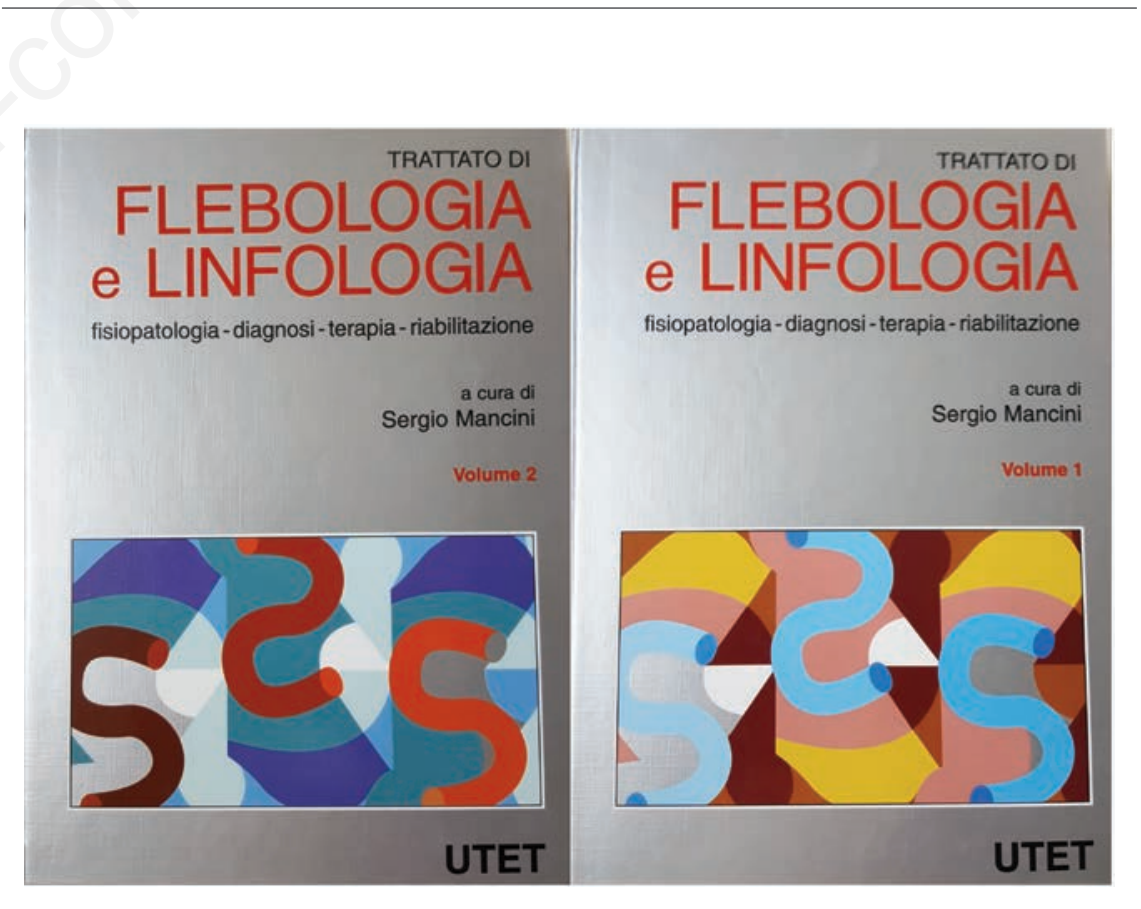

Figure 4. Handbook on Phlebology (vol. 1-2), The experience of the Senese School. 


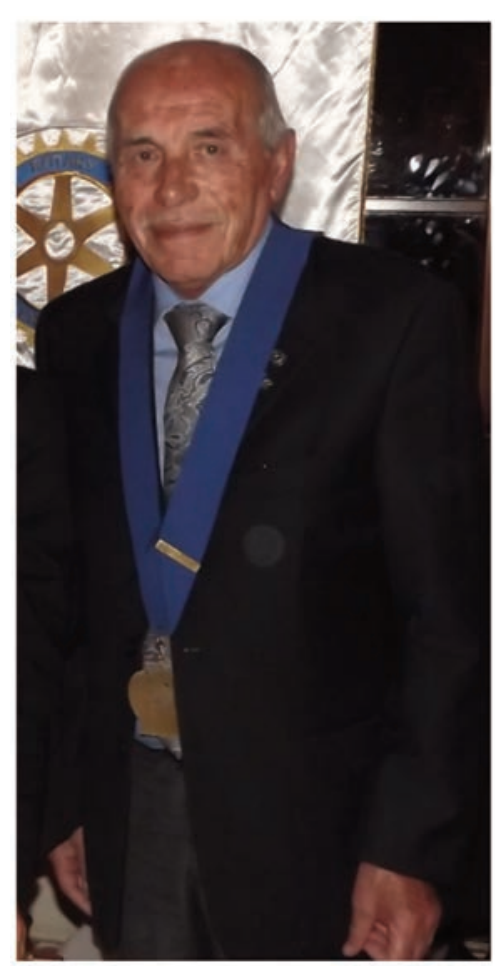

Figure 5. Professor Sergio Mancini.

his assistant Professor Giuseppe Botta.

I want to conclude this memorial of my father (Figure 5) by quoting the words he used in the acknowledgments of his last publication:

As a conclusion of this handbook, I would like to recall with deep affection all the physicians who have been close to me, who have never hesitated in giving their heart and soul to the growth of this Phlebolymphology Center; who in all these years have worked tirelessly, expressing the essence and dedication of the true nature of the doctor's mission.

Pier Antonio Bacci, Giulia Baldoni, Francesca Berna, Mirko Belcastro, Giuseppe Botta, Matteo Bucalossi, Ranieri Caldarone, Vittoria Cassioli, Stefano Ciatti, Alessia Comandi, Francesco Consiglio, Ubaldo Dati, Gianluca Delle Monache, Alessandro Fiorini, Andrea Gazzabin, Antonella Grassi, Francesco Griccioli, Rosa Intermite, Federica Lasseur, Giovanni Marcocci, Stefano Mancini, Fabrizio Mantovani, Fabrizio Mariani, Stefano Martelli, Simonetta Massi, Martina Menchinelli, Ivo Migliorini, Annamaria Peccatori, Annalisa Piccinetti, Mauro Poggialini, Carla Ruggeri, Donatella Spadi, Giulio Tommasino.

\section{References}

1. Mariani F. Le Centre Phlébologique de Sienne. Phlébologie 1986;39:677-85.

2. Mancini S, Mariani F, Di Stefano A, et al. Modification des enzymes lysosomiales dans le sérum des maladies variqueuses. In: Davy A, Stemmer R (eds), Phlébologie '89, $10^{\circ}$ Congrés Mondial Union Internationale de Phlébologie. Paris: John Libbey Eurotext Ltd.; 1989. pp 53-55.

3. Mancini S, Caldarone R, Mariani F, et al. Ulcers caused by physical or chemical injury. In: Westerhof W (ed.), Leg Ulcers: Diagnosis and Treatment. Amsterdam: Elsevier Science Publishers; 1993. pp 213-38.

4. Mancini S, Botta G, Massi S, et al. Clinical experimentation of a new microfibrillar structure cellulose membrane called "bioprocess" on ulcers found on the lower limbs: 50 cases reports. Phlébologie 1992;2:1342-4.

5. Mancini S, Botta G, Mancini S. Consiglio F. Gli innesti cutanei. In: Mancini S (ed.), Trattato di Flebologia e Linfologia. Vol. 2. Torino: UTET; 2001. pp 705-9.

6. AA.VV. A polyuretanic foam (BiatainTM) in ulcers treatment. Atti XIV Congresso Mondiale della Union International de Phlebologie, Roma 9-
14 settembre 2001, abstract: 101

7. Mancini S. La terapia delle ulcere venose degli arti inferiori. Sarzana: Grafica Sturli; 1990.

8. Botta G, Massi S, Ruggieri C, et al. The short stripping saphenectomy in the varices of the lower limbs. Phlébologie 1995;1:385-7.

9. Botta G, Massi S, Ruggieri C, et al. The recurrent varicose veins of the lower limb. Phlébologie 1995;1:388-90.

10. Botta G, Mancini St, Berna F, et al. Prevention of recurrent varicose veins in the groin after surgery. Atti XV Congresso Mondiale UIP - Rio de Janeiro 2005. Int Angiology 2005;24:18.

11. Delle Monache G, Piccinetti A, et al. Etude écographique et traitement chirurgical de l'insufficience de la saphéne antérieure de cuisse. Phlébologie 2003;3:229-32.

12. Mancini S, Mariani F. La plastique externe de la valvule préostiale dans l'insuffisance de la cross saphénofemorale. Etudes expérimentales et cas cliniques. Phlébologie 1991;44:763-9.

13. Botta G, Lorenzi M, Intermite R, et al. The correction of deep venous reflux with venocuff. Phlebology 1995;1:9879.

14. Botta G, Belcastro M, Mancini S, et al. Both subterminal greater saphenous vein valve and wall are not affected by lymphomonocyte infiltration in primary chronic venous insufficiency. Acta Phlebologica 2001;2:1-6.

15. Mancini S, Mariani F, De Sando D, et al. La sclérose de la grande saphene. Histologie et microscopie electronique des alterations chez l'homme. In: Davy A, Stemmer R (eds.), Phlébologie '89, $10^{\circ}$ Congrés Mondial Union Internationale de Phlébologie. Paris: John Libbey Eurotext Ltd.; 1989, pp 769-771.

16. Mancini S, Lasseur F, Mariani F. La sclérose de la veine grande saphéne: étude expérimentale chez l'homme sur l'action sclérosante de la solution iodoiodurée et le polidécane (histologie et microscopie électronique). Phlébologie 1991;44:461-8.

17. Mariani F, Bianchi V, Mancini S, Mancini S. Teleangectases in venous insufficiency: point of reflux and treatment strategy. Phlebology 2000;15:3842.

18. Izzo M, Mariani F, Mancini S. Il trattamento delle pigmentazioni post-scleroterapia. In: AA.VV. Medicina Estetica-Obesità, Insufficienza venosa cronica, Malattia Varicosa, Linfedema. Roma: Ed. Salus Internazionale; 2000, 
pp 263-266.

19. Botta G, Piccinetti A, Gontella M, Mancini S. Il potenziamento dell'attività di pompa venosa del tricipite surale in ortopedia e traumatologia medialnte l'utilizzo di una nuova apparecchiatura di ginnastica vascolare. Giorn Ital Ortop Traumatol 2001;37:84-8.

20. Mancini S, Mariani F. La scleroterapia della vena grande safena. Considerazioni cliniche e sperimentali. In: Brizzio EO, Leibaschoff $\mathrm{G}$ (eds), Flebologia Estetica. Buenos Aires; 1990, pp 157-170.

21. Mancini S, Volterrani L, Botta G, et al. Compression of the lower limbs by elastic stocking: a morphological study of the peripheral veins with T.A.C. Phlébologie 1992;2:891-3.

22. Ruggieri C, Massi S, Peccatori AM, et al. Comparative morphometric study of the therapeutic effect of compression and saphenectomy carried out on cutaneous biopsies in patients affected by peripheral chronic venous insufficiency. Phlebology 1995;138-40.

23. Bacci PA, Mancini S. Flebectomia ambulatoriale estetica. Colle di Val D’Elsa, Siena: Laris; 2009.

24. Bacci PA, Mancini S. Le traitment medical. Phlebological 89. JBE 1989:65962.

25. Bacci PA, Allegra C, Mancini S, et al. Randomized placebo controlled double blind clinical study on efficacy of a multifunctional plant complex in the treatment of the so called cellulitis. J Aesthet Surg Dermatol Surg 2003;5:1.

26. Bacci PA, Mancini S. La flebochirurgia con laser YAG. Acts of the 2nd International Congress of Phlebology, 12 settembre 1993, Siena, Italy.

27. Viviani C, Bacci PA, Mancini S. Complicazioni ed emergenze in chirurgia ambulatoriale. Milano: Mediamix; 1996.

28. Botta G, Delle Monache G, Gazzabin A, et al. Lo stripping della grande safena in anestesia loco-regionale. Atti del $5^{\circ}$ Congresso Internazionale One Day Surgery, 4-6 Jun 1997, Verona, Italy, paper $n^{\circ} 3$.

29. Botta G, Pede O, Delle Monache G, et al. Protocollo di accesso alla One Day Surgery per intervento chirurgico di safenectomia. Atti del $5^{\circ}$ Congresso Internazionale One Day Surgery, 4-6 Jun 1997, Verona, Italy, paper $\mathrm{n}^{\circ} 5$.

30. Mancini S, Muzzarelli R, Mancini S. La terapia con metilpirrolidone chitosano. In: Mancini S (ed.), Trattato di flebologia e linfologia. Vol. 2. Torino: UTET; 2001. pp 671-680.

31. Tullii RE, Vaccari R, Mancini S. Late results of venous leakage surgery. 6th World meeting on Impotence, Singapore 12-16 Sept 1994. Int J impotence Res 1994;6:D196.

32. Mancini St, Tullii RE, Guillaux C, et al. Penile veno-occlusive dysfuncion: it's a polidistrict venopathy expression? Atti di International Congress of Phlebology, 4-8 Sept 1996, Corfù, Grecia, pp 224.

33. Tullii RE, Mancini RE, Guillaux C, Mancini S. Surgical correction of venoocclusive dysfunction: follow-up at 10 years. Atti di International Congress of Phlebology, 4-8 Sept 1996, Corfù, Grecia, pp 225.

34. Tullii RE, Guillaux C, Mancini S, et al. Penile lipofilling. VII World Meeting of Impotence, San Francisco, 3-7 Nov 1996. Int J Impotence 1889;8:D156.

35. Baccetti BM, Bruni E, Capitani S, et al. The sub-inguinal correction technique was developed, and particularly ultrastructural changes of sperm, and chromosome 18, $\mathrm{X}$ and $\mathrm{Y}$ aneuploids in III degree varicocele. J Androl 2006;27:94101.

36. Mancini S, Bulotta AL, Molinaro F, et al. Surgical Retroperitoneoscopic and Transperitoneoscopic Access in Varicocelectomy: Duplex Scan Results in Pediatric Population. J Pediatr Urol 2014;10:1037-42.

37. Mancini S, Piccinetti A, Nappi G, et al. Clinical, functional and quality of life changes after balneokinesis with sulphurous water in patients with varicose veins. Vasa 2003;32:26-30.

38. Curti C, Mangano A, Guasconi A, Mancini S. Terapia integrate delle insufficienze flbolinfatiche. $1^{\circ}$ Congresso Nazionale Congiunto della Società Italiana di Flebologia. Siena 23-25 Sept 1996. Flebolinfologia 1996;199:64.

39. Curti C, Mancini S, Mangano A. Trattamento delle lesioni trofiche vascolari con con luce polarizzata. $1^{\circ}$ Congresso Nazionale Congiunto della Società Italiana di Flebologia. Siena 2325 Sept 1996. Flebolinfologia 1996;199:62.

40. Curti C, Mangano A, Mancini S. Cellulite: squilibrio bioenergetico dell'unità psicofisica dell'uomo. Cause, effetti e terapia. $1^{\circ}$ Congresso Nazionale Congiunto della Società Italiana di Flebologia. Siena 23-25 Sept 1996. Flebolinfologia 1996;199:65.

41. Longo L, Mariani F, Corcos L, et al. Lasers in Phlebology: state of the art. In: Weidelich $\mathrm{W}$, Weidelich $\mathrm{R}$, Waldschmidt $\mathrm{J}$ (eds.), Laser in der Medizin Laser in Medicine. Berlin: Springer-Verlag Berlin Heidelberg;
1998. pp 106.

42. Longo L, Botta G, Dal Maso M, Mancini S. Therapeutic, Laser Videocapillaroscopy for the teleangiectasias. Laser Surg Med 1997;9:39.

43. Longo L, Gazzabin A, Botta G, et al. Laser surgical cleansing of cutaneous ulcers. Laser Technol 1999;9:19.

44. Piccinetti A, Botta G, Delle Monache G, Mancini S. Diagnostic protocol in post-mastectomy upper limb lymphedema. European Congress of Union International Phlebologie. Bremen: Vasomed; 1999. pp 60.

45. Piccinetti A, Botta G, Delle Monache G, Mancini S. Protocollo diagnostico/terapeutico del flebolinfedema degli arti inferiori. Med Est 2001;25:75.

46. Mancini S, Bucalossi M, Gazzabin L, et al. Valutazione a 5 anni degli innesti omologhi cutanei. Acta Phlebol 2005;6:48-9.

47. Mancini S. Treatment of leg ulcers with allograft skin. Acta Phlebol 2002;3:95100 .

48. Mancini S, Mancini S, Botta G. Innesto cutaneo omologo. In: Genose G (ed.), La chirurgia delle vene e dei linfatici. Milano: Ed Masson; 2003. pp 195-8.

49. Mancini S. La banca della cute. In: Guarnera G (ed.), Ulcera venosa: dalla clinica alla terapia. Roma: Litografia Saba; 2006. pp 125-41.

50. Mancini S, Bucalossi M, Gazzabin L, Mancini S. Trattamento delle lesioni cutanee con gel piastrinico. Acta Phlebol 2008;6:63-8.

51. Mancini S. Trattato di Flebologia e Linfologia. Fisiopatologia-diagnosi-terapia-riabilitazione. Torino: UTET; 2001.

52. Mariani F, Bucalossi M, Mancini S. Selective vs Radical crossectomy of the Great Saphenous Vein in primary Venous Insufficiency: results at five years. Int Angiol 2013;32:61.

53. Mariani F, Mancini S, Bucalossi M, Allegra C. Selective high ligation of the saphenofemoral junction decreases the neovascularization and the recurrent varicose veins in the operated groin. Int Angiol 2015;34:250-6.

54. Tommasino G, Cassioli V, Menchinelli $\mathrm{M}$, et al. Crossectomy and foam sclerotherapy in the treatment of chronic venous insufficiency. XXI Congresso Nazionale Società Polispecialistica Italiana Giovani Chirurghi, Perugia 2008. Eur Surg Res 2008;41:92.

55. Agus GB, Mancini S, Magi G. The first 1000 cases of Italian Endovenous-laser Working Group (IEWG). Rationale, and long-term outcomes for the 1999-2003 
period. IEWG. Int Angiol 2006;25:20915.

56. Mariani F, Mancini S. Scleroterapia. Torino: Ed. Minerva Medica; 2006.

57. Mariani F (ed.), Compression. Consensus Document based on Scientific Evidence and Clinical Experiences. Torino: Minerva Medica; 2009.

58. Mariani F, Rastel D, Uhl JF, Lun B. The interface pressure exerted by medical compression stocking. Acta Phlebol 2007;8:31-9.

59. Mariani F, Bucalossi M, Mancini S. Placebo controlled efficacy of class 2 elastic stockings (23-32 $\mathrm{mmHg}$ ) in reduction of edema in CVI of the lower limbs. Acta Phlebol 2013;14:39-44.

60. Mariani F, Mattaliano V, Mosti G, et al. The treatment of venous leg ulcers with a specifically designed compression stocking kit. Comparison with bandaging. Phlebologie 2008;4.
61. Agus GB, Allegra C, Antignani PL, et al. Linee Guida sulla diagnosi e terapia dell'insufficienza venosa cronica. Acta Phlebol 2000;1:1-40.

62. Agus GB, Allegra C, Antignani PL, et al. Linee Guida sulla diagnosi e terapia della malattia trombo embolica. Acta Phlebol 2000;1:41-55.

63. Agus GB, Allegra C, Antignani PL. Linee Guida sulla diagnosi e terapia delle malattie dei linfatici. Acta Phlebol 2000;1:57-69.

64. Agus GB, Allegra C, Arpaia G, et al. Guidelines on compression therapy. Acta Phlebol 2001;20:1-37.

65. Agus GB, Allegra C, Arpaia G, et al. Guidelines for the diagnosis and treatment of chronic venous insufficiency. Int Angiol 2001;20:1-37.

66. Agus GB, Allegra C, Arpaia G, et al. Guidelines for the diagnosis and treatment of thromboembolic disease. Int Angiol 2001;20:39-52.
67. Agus GB, Allegra C, Arpaia G, et al. Guidelines for the diagnosis and treatment of lymphatic disease. Int Angiol 2001;20:53-64.

68. Agus GB, Allegra C, Arpaia G, et al. Linee Guida per la diagnosi e la terapia delle malattie delle vene e dei linfatici, Revisione 2003 Collegio Italiano di Flebologia (eds). Acta Phlebologica 2003;4:1-52.

69. Agus GB, Allegra C, Antignani PL, et al. Guidelines for the diagnosis and therapy of the vein and lymphatic disorders. Int Angiol 2005;24:107-68.

70. Agus GB, Allegra C, Arpaia G, et al. Linee Guida per la diagnosi e la terapia delle malattie delle vene e dei linfatici, Revisione 2013 Collegio Italiano di Flebologia (eds). Acta Phlebol 2013;14.

71. Mancini S. Manuale di flebologia, esperienza della scuola senese. Colle di Val d'Elsa, Siena: Ed. Laris; 2009. 